\title{
FUNCTION EQUILIBRIUM IN THE MEDIUM AND LARGE URBAN SETTLEMENTS OF SERBIA
}

\author{
Branka Tošić ${ }^{*}$, Zora Živanović ${ }^{*}$, Teodora Nikolić ${ }^{*}$ \\ "University of Belgrade - Faculty of Geography, Belgrade
}

\begin{abstract}
The aim of this paper is to analyze and assess direction and intensity of changes in structure of activities in urban settlements in Serbia with more than 20,000 inhabitants, to determine the tendencies of that process, as well as the moment or the period of achieving their equilibrium structure of development activities. In addition, this paper defines the regularities of functional urban areas changes depending on their demographic size, on one hand, and depending on the period of exercising their convergent - uniform structure, on the other hand. Results of the analysis were used for testing the hypotheses put forward in the context of previous research related to the period of most intense industrialization - 60s and 70s of the last century. While in this paper, for comparison, that period of time was covered, the focus of the research refers to the period 1981-2011.
\end{abstract}

Key words: activity, equilibrium structure, the size of urban settlements, the latest period, Serbia.

\section{Introduction}

Population distribution and its activity are a result of the space potential, natural and socio-economic influences, but also a result of polarization in fluences of centers in the network of settlements in the study area. The structure of the active population activities which are presented through activities sectors,

${ }^{1}$ Corresponding author: B. Tošić, University of Belgrade - Faculty of Geography, Studentski trg 3/III, 11,000 Belgrade, Serbia; e-mail: branka.tosic12@gmail.com 
as well as their changes, is one of the key indicators for monitoring the development of settlements and centers. Structure of activities of the population is an indicator which is being used for establishing spatial-function relationship which affect the settlements transformation (Tacoli, 1997). Activity sectors relations were the basis for defining numerous methods that are used in urban-geographical studies in the first half of the twentieth century in developed countries, and in the period after the Second World War in Serbia, given that half of the twentieth century is time of beginning of a well-known deagrarization and industrialization process in the region. The most intense changes of structure of activities at the earliest occurred in urban settlements with larger population and over time this process included both middle-sized and then smaller urban settlements. Serbian urban settlements with more than 20,000 inhabitants, or their function structure, organization and development tendencies represent the most active category of settlements in encouraging further development and transformation of the space. Population and functional changes are interdependent and are caught in the constant cumulative development process, and at a later period morphological changes were monitored as well.

The study of functional changes in urban settlements and their development impact in the area is of great importance in planning the organization of space, directly affects the distribution of the population, construction of industrial facilities and facilities of social standards, the influence on traffic planning and improving the accessibility, etc. (Тошић, 1997).

\section{Overview of previous research}

Many concepts that explain the functional organization of space and settlements, according to the results of the analysis of the structure of activities, occurred primarily by the influence of the industrialization process. Regardless of the fact that these concepts date back to the beginning of the twentieth century, they have been elaborated intensively in the mid-century, when structural changes in cities in the developed part of the world gained larger intensity. The corpus of scientific concepts on the use of functional structures is quite layered with many elements that connect them but also separates them, given that each of them deals with different ways of thinking. Since it is a development as a process, the main sources are, however, from the social and economic science where in the economic effects on structural changes are stronger. They are reflected in the initial growth across the manufacturing industry, as the main initiators of development changes 
and defining economic theories, based on various stages of development. Economic parentage is dominant, what can be explained by the fact that the economy is creating wealth and through its distribution and use subsequent social changes largely occur, which are all expressed in different ways in the cities, and later in the wider environment. In the context of the assumption that they are structural development changes in the initial phase are associated with economic growth, we shall mention one of the main concepts that is directly related to the economic growth or the technical progress as a key driving force of development as a whole.

Model ofeconomic sectors, which is formulated by British economists Clark and Fisher, is based on the assumption that social-economic development promotes the general, special and technical division of labor and differentiation of activities. Consequently, it comes to structural changes and changes in the number of employees by economic sectors and activities over a certain period of time. The main sectors of activities that follow the model are: primary, secondary and tertiary-quaternary sector. The application of the model determines whether there is a link between income per capita and changes in the structure of employees by sectors of activity. Empirically, it is found that decrease of employment in the primary, and increase of employment in the secondary and tertiary-quaternary sector, and the subsequent transition of employees from secondary to tertiary-quaternary, income per capita is rising.

This model has found its application in the research related to the stages of development of cities and their surrounding settlements in Serbia (Вељковић, Јовановић, Тошић, 1995). Based on demographic changes and changes in the sectors of activity of the active population (degree of deagrarization) in the city and surrounding settlements, four stages of the city development are defined.

Determination of the function settlement type in a particular area is performed on bases of the structure of the active population per activity (Fehre, 1971). According to the share of the primary sector activities the following types of settlements can be singled out: extremely non-agricultural, nonagricultural, mixed type settlements and agricultural settlements. A similar typology, with balanced involvement of all three sectors, was performed according to the same methodology at the division to: agricultural, agricultural-industrial, agricultural-service, industrial, industrial-agricultural, industrial-service, service, service-agricultural and service-industrial settlements. 
By applying the deviation in the share of the activity of settlements, with respect to the same indicator in a wider area, the degree or index of diversification of certain businesses, or index of redundancy is provided, and hence the deviation of settlements from the area average. Using a minimum employment Ullman and Dacey have classified the cities according to the degree of functional diversification, and specialization (Vresk, 2002). By calculating the deviations from the "minimum" of employment for all sectors of activity, specialization indices of US cities were obtained. One example of the classification of cities in the second half of the twentieth century, but which is using factor analysis based on a number of variables, is the division of British cities (Moser, Scott, 1961) on: the primarily in industrial cities with five subtypes, cities of commerce, administration and recreational activities with three subtypes and suburbia with six subtypes.

The functional classification of cities in the territory of the former Yugoslavia was done by (Vogelnik, 1961) according to the share of the industry, and functional orientation was graded as follows: specialization, navigation, small character without character. In the area of Croatia, Milan Vresk (Vresk, 1996), also classified cities according to the 'average' Croatian city. On the territory of Serbia V. Đurić, O. Savić, A. Veljković, D. Tošić et al. have dealt with above mentioned classification and application of methods.

To determine the settlements centrality and the status and importance of the village in the network, quantitative approach was used as well, based on the share of tertiary-quaternary activities which are considered a key factor in providing services to surrounding settlements. Degree of settlements centrality in the region is being determined by the share of active population in service activities in total active population in the settlement, in relation to the same indicators in the region (Schmook, 1968). Using the service share of development activities as a criterion, therefore, defines the degree of city nodality (Вељковић, et al. 1995, Живановић, 2015). Although the structure of the activities is still a relevant indicator of development position of the settlement, available indicators related to convergent commuter towns in the immediate environment gain importance in defining nodality (Тошић, 2012).

Active population by activity sectors which carries interest can be used to establish the hierarchy of settlements in the network, not only on the principle of presence of the service sector but the production sector as well. The same parameters can be used as the "mass" in application of social physics methods (Newton's law of gravity, Reilly model; Vresk, 2002) for calculating gravitational impacts of centers. 
In recent years, in the area of our country, we emphasize study which analyze the industrialization and structural changes caused by that process, which are the main drivers and carriers of sustainable economic development. It is pointed out that the industry of the Republic of Serbia is devastated, due to the sudden and premature tertiarization and inadequate reforms (Mićić, 2015). In the regional environment, explicit analysis of the relationship of the structure of activities was also observed. Research in Croatia are related to the change in the structure of activities of the active population in the postindustrial era (Peračković, 2011), and on the case of a major Slovenian cities employed population of developmental activities that migrate to the place of work has been analyzed (Bole, 2011).

Paper by Romanian authors deals with tertiarization inside the industrial parks in the capital city, in close connection with deindustrialization and industrial delocalization (Cercleux, Peptenatu, Merciu, 2015). An example of research in Portugal is also cited, where it was confirmed that the increase and diversification of foreign direct investment coincided with the tertiarization of the economy, being closer to the productive specialization pattern of the country, while continuing to focus mainly on manufacturing (Melo, Ferreira-Lopes, Monteiro, 2015). Investigation of M. Lobanov (2014) is resulted in the determination of the possible structural changes and prospects of the territorial-production formations in CEE in the post-crisis period. Talking about regional disparities in Turkey, Umut (2016) confirms that the "east-west dualism almost disappears with regard to human capital at the tertiary educational level, which is heavily concentrated in Turkey's major cities (Istanbul, Ankara, Izmir, Kocaeli, and Bursa)".

In non-European countries, the new period indirectly uses activity sector analysis, exploring the metropolises in Canada, where are authors proposed to incorporate certain hypotheses from the knowledge-intensive business services (KIBS) in particular possible spillover effects, synergies between economic sectors and labor market effects, into the spatial analysis (Shearmur, Doloreux, 2008). Another example is research that applies a task-based approach to measure and interpret changes in the employment structure of the 168 largest cities in the US in the period 1990-2009 (Kok, Weel, 2014). Paper that shows how to develop a Structure-based analysis addressing how the network of interdependencies among occupational specializations affects the ease with which urban economies can transform themselves is also cited (Muneepeeraku, et al. 2013). The Japanese author Yoshito Hirata (2016) proposed a mathematical model for temporal changes of proportions for industrial sectors. He proved that the model keeps the proportions for the primary, 
secondary, and tertiary sectors for the future period. Sridhar (2017) gives the research results about the specializations and its process of Indian cities and towns, as well as about "the specialization identified as a result of local advantages versus industry or national economic growth". The analyses of the Northeast region of Brazil show that "education and worker experience are the most relevant variables to explain the high index of inequality in earnings in both the rural and urban areas" (Santos, Vieira, 2015).

\section{The process of changing the structure of activities in the urban settlements of Serbia}

The paper focus on changes of the structure of activities of urban settlements in Serbia with population larger than 20,000 inhabitants, which are 39, for a period of 1981-2011. with the aim of determining the tendency of structural process in relation to the rules established by previous research in the period 1961-1981., which is defined by A. Veljkovic and his associates in the study 'Cities of Serbia - development centers in the network of settlements "(Вељковић, et al., 1995). Specifically, as a result of research of structure of activities of 90 Serbian urban settlements (52 from Central Serbia, 28 in Vojvodina and 10 in Kosovo and Metohija) in the period from 1961 to 1981., the authors observed a series of regularities in the development of urban settlements, whose verification will be dealt with in this paper. Those regularities are:

- the evolutionary development of the structure of activities in some urban settlements from lower to higher and more developed forms,

- convergent development of the structure of activities in middle and larger urban settlements and

- dependence of population increases of the urban settlements from the level of development of the urban settlements and the nature of its structure activities.

Our research will include determining the moment (census period) for achieving the equilibrium structure of development activities, as well as verification of the hypotheses put forward as part of this research.

\section{The evolutionary development of the structure of industry in urban settlements in Serbia}

These methodological concepts and studies that are based on usage of share of sector activity has been questioned, especially when it comes to 
the facts that are recognized in the period of transition of Eastern European countries, including Serbia. Specifically, as a result of industrial collapse in less developed areas, the proportion of employees in tertiary activitiesis growing rapidly, as extensive tertiarization, so-called quasi-tertiarization (or para-tertiarization), which includes the existence of "gray economy" and employment in "petty trade", service activities, hospitality management etc. It ostensibly indicates the higher level of development, given that the process of deagrarization is directly "aimed" towards service industries, rather than production. In support of the above goes evidently low quality of service that is far below the one that characterizes objectively highly developed structure of activities, created as a result of the transition to a higher phase of development due to greater representation of modern industries, profitable, technological, i.e. capital-intensive, which do not have the need for a large number of workers. In contrast to the less developed regions of our country, "the decline in traditional industry participation in the creation of gross domestic product and the employment of the population in most developed countries is not caused by the destruction of the industry of these countries, but is conditioned by the development of new activities that provide high levels of newly created values" (Тошић, 2012). Deindustrialization in the territory of Serbia has just determined the further development of economic structure and change of structure in the activities sector of settlements.

However, in terms depending on the statistical data for territory of Serbia that are available exclusively for the activity or activity sector, monitoring changes in the structure of activities through employment, i.e. active population performing an occupation can be considered purposeful (due to the fact that data on income earned by activities even at the local level are not published since 2006).

In addition to the previous findings, testify the data on the increasing presence of tertiary-quaternary activity sector in the period 1981-2011., while the secondary sector in most urban areas have lost its primacy. In fact, according to data of the 1991 census, out of 39 tested urban settlements there were 21 towns in which the secondary sector was dominant (all settlements also recorded an increase in population), in 2002 that number decreased to only 7 , provided that it comes off in the settlements with 20,000 to 50,000 inhabitants, mainly with the increase in population (in only two settlements in which still dominates the secondary sector of the economy reducing the population is present). According to Census data 2011 in all tested settlements tertiary-quaternary sector is dominant (except Lazarevac) and with a higher percentage of the share, relative to the share of the secondary sector, by $30 \%$ on average (Table 1,2 and 3 ). 
On intensity of the domination of tertiary-quaternary sector in the structure of activities in settlements with more than 20,000 inhabitants show data from tables no. 1, 2 and 3. More than $60 \%$ of employees in tertiary-quaternary sector in 1991 was recorded only in Belgrade and Novi Sad. Number of urban settlements with such a significant dominance of tertiary-quaternary sector in the structure of activities in 2002 was considerably increased (to 11, of which 3 with a reduced population) and according to the Census 2011, the number was up to 33 (from 39 tested settlements), of which only 12 with increased population.

Table 1 - Employment by activities sectors in 1991. and changes in population from 1981 to 1991.

\begin{tabular}{|c|c|c|c|c|c|c|c|c|c|}
\hline \multirow{2}{*}{$\begin{array}{l}\text { Employment by } \\
\text { activitiessectors }\end{array}$} & \multicolumn{3}{|c|}{$\begin{array}{l}\text { The total number of } \\
\text { centers }\end{array}$} & \multicolumn{3}{|c|}{$\begin{array}{l}\text { Number of centers } \\
\text { with the increase in } \\
\text { population 1981-1991 }\end{array}$} & \multicolumn{3}{|c|}{$\begin{array}{l}\text { Number of centers } \\
\text { with a decrease in } \\
\text { population 1981-1991 }\end{array}$} \\
\hline & $\begin{array}{l}20,000- \\
50,000\end{array}$ & $\begin{array}{l}50,000- \\
100,000\end{array}$ & $\begin{array}{c}> \\
100,000\end{array}$ & $\begin{array}{l}20,000- \\
50,000\end{array}$ & $\begin{array}{c}50,000- \\
100,000\end{array}$ & $\stackrel{>}{100,000}$ & $\begin{array}{l}20,000- \\
50,000\end{array}$ & $\begin{array}{l}50,000- \\
100,000\end{array}$ & $\begin{array}{c}> \\
100,000\end{array}$ \\
\hline $\mathrm{s} / \mathrm{tq}>1$ & 13 & 7 & 1 & 13 & 7 & 1 & / & / & / \\
\hline $0<\mathrm{s} / \mathrm{tq}<1$ & 9 & 6 & 3 & 7 & 6 & 3 & 2 & / & / \\
\hline $\operatorname{tq}>60 \%$ & / & / & 2 & / & / & 2 & / & / & / \\
\hline
\end{tabular}

$\mathrm{s}$ - share od employed in the secondary sector; tq - share od employed in tertiary-quaternary sector Source: SZS (1981); P3C (1991); P3C (20046).

Table 2 - Employment by activities sectors in 2002. and changes in population from 1991 to 2002.

\begin{tabular}{|c|c|c|c|c|c|c|c|c|c|}
\hline \multirow{2}{*}{$\begin{array}{l}\text { Employment by } \\
\text { activitiessectors }\end{array}$} & \multicolumn{3}{|c|}{$\begin{array}{l}\text { The total number of } \\
\text { centers }\end{array}$} & \multicolumn{3}{|c|}{$\begin{array}{l}\text { Number of centers } \\
\text { with the increase in } \\
\text { population 1991-2002 }\end{array}$} & \multicolumn{3}{|c|}{$\begin{array}{c}\text { Number of centers } \\
\text { with a decrease in } \\
\text { population 1991-2002 }\end{array}$} \\
\hline & $\begin{array}{l}20,000- \\
50,000\end{array}$ & $\begin{array}{l}50,000- \\
100,000\end{array}$ & $\begin{array}{c}> \\
100,000\end{array}$ & $\begin{array}{l}20,000- \\
50,000\end{array}$ & $\begin{array}{l}50,000- \\
100,000\end{array}$ & $\begin{array}{c}> \\
100,000\end{array}$ & $\begin{array}{l}20,000- \\
50,000\end{array}$ & $\begin{array}{l}50,000- \\
100,000\end{array}$ & $\begin{array}{c}> \\
100,000\end{array}$ \\
\hline $\mathrm{s} / \mathrm{tq}>1$ & 7 & 1 & I & 5 & 1 & 1 & 2 & 1 & 1 \\
\hline $0<\mathrm{s} / \mathrm{tq}<1$ & 15 & 13 & 4 & 8 & 10 & 2 & 7 & 3 & 2 \\
\hline $\mathrm{tq}>60 \%$ & 2 & 5 & 4 & 1 & 5 & 2 & 1 & 0 & 2 \\
\hline
\end{tabular}

$\mathrm{s}$ - share od employed in the secondary sector; tq - share od employed in tertiary-quaternary sector Source: P3C (1991); P3C (2004a); P3C (20046). 
Function Equilibrium in the Medium and Large Urban Settlements of Serbia

Table 3 - Employment by activities sectors in 2011. and changes in population from 2002 to 2011.

\begin{tabular}{|c|c|c|c|c|c|c|c|c|c|}
\hline \multirow{2}{*}{$\begin{array}{l}\text { Employment by } \\
\text { activitiessectors }\end{array}$} & \multicolumn{3}{|c|}{$\begin{array}{l}\text { The total number of } \\
\text { centers }\end{array}$} & \multicolumn{3}{|c|}{$\begin{array}{l}\text { Number of centers } \\
\text { with the increase in } \\
\text { population } 2002-2011\end{array}$} & \multicolumn{3}{|c|}{$\begin{array}{l}\text { Number of centers } \\
\text { with a decrease in } \\
\text { population 2002-2011 }\end{array}$} \\
\hline & $\begin{array}{c}20,000- \\
50,000\end{array}$ & $\begin{array}{l}50,000- \\
100,000\end{array}$ & $\begin{array}{c}> \\
100,000\end{array}$ & $\begin{array}{l}20,000- \\
50,000\end{array}$ & $\begin{array}{l}50,000- \\
100,000\end{array}$ & $\begin{array}{c}> \\
100,000\end{array}$ & $\begin{array}{l}20,000- \\
50,000\end{array}$ & $\begin{array}{l}50,000- \\
100,000\end{array}$ & $\begin{array}{c}> \\
100,000\end{array}$ \\
\hline $\mathrm{s} / \mathrm{tq}>1$ & 1 & / & / & 1 & / & / & / & / & / \\
\hline $0<\mathrm{s} / \mathrm{tq}<1$ & 21 & 13 & 4 & 5 & 6 & 4 & 16 & 7 & / \\
\hline $\mathrm{tq}>60 \%$ & 17 & 12 & 4 & 3 & 5 & 4 & 14 & 7 & / \\
\hline
\end{tabular}

$\mathrm{s}$ - share od employed in the secondary sector; tq - share od employed in tertiary-quaternary sector

Source: P3C (2002); P3C (2004a); P3C (20046); P3C (2014a); P3C (2014б).

During the period 1981-2011 the share of employees in the secondary sector is decreased in all tested urban settlements, the average of 20 percentage points, while the largest decrease, of over 30 percentage points, was recorded only in Novi Pazar and Mladenovac, a decrease of 20-30 percentage points to 19 urban settlements, a decrease of 10-20 percentage points in the 13 urban settlements, and to less than 10 percentage points in the 5 urban settlements. In cities with a population of 50,000 - 100,000 inhabitants is the most intense decrease in the share of employees in the secondary sector (table 4).

In the period from 1981 to 2011. the proportion of employees in tertiary-quaternary sector has increased in the analyzed urban areas, the average of 22.45 percentage points (Table 4), with an increase of over 30 percentage points recorded in Novi Pazar, Mladenovac, Leskovac, Prokuplje and Pančevo, increase of 20-30 percentage points in 22 urban areas, an increase of 10 to 20 percentage points to 11 urban areas and increase of less than 10 percentage points only in Lazarevac (4.54). In cities with a population of 50,000 to 100,000 is more intense increase in the share of employees in tertiary-quaternary sector in relation to urban areas with smaller population $(20,000$ to $50,000)$ by about 5 percentage points. In the group of large cities, intensive growth of the share of employees of the tertiary-quaternary sector for about 10 percentage points was recorded in Kragujevac, compared to other cities (Belgrade, Novi Sad and Niš, with a value of this indicator of around 16\%), in which the process is implemented before 1981. 
Table 4 - Change of activities sectors, the period of 1981-2011.

\begin{tabular}{|l|c|c|c|}
\hline $\begin{array}{l}\text { Population in } \\
\text { centers }\end{array}$ & $\begin{array}{c}\text { Number } \\
\text { of } \\
\text { centers }\end{array}$ & $\begin{array}{c}\text { The average decrease } \\
\text { in participation of } \\
\text { the secondary sector } \\
\mathbf{1 9 8 1 - 2 0 1 1 . ~}\end{array}$ & $\begin{array}{c}\text { The average increase } \\
\text { in participation of the } \\
\text { tertiary-quaternary sector } \\
\text { 1981-2011. }\end{array}$ \\
\hline$>100,000$ & 4 & -18.44 & 18.70 \\
\hline $50,000-100,000$ & 13 & -24.35 & 25.74 \\
\hline $20,000-50,000$ & 22 & -17.31 & 21.19 \\
\hline total & 39 & -19.45 & 22.45 \\
\hline
\end{tabular}

Source: authors

In the analyzed period (1981-2011) in the major cities the decrease of the share of employees in the secondary sector was nearly identical to its increase in tertiary-quaternary sector. The urban settlements with 50,000 to 100,000 inhabitants the increase of the share of employees in tertiary-quaternary sector exceeds the decrease of the share of the employed in the secondary sector, which shows still slightly present process of transition from agricultural to nonagricultural activities. This process is more intensively emphasized in urban settlements with 20,000 to 50,000 inhabitants, with a difference of almost 4 percentage points.

According to Census data from 2011, the share of employees in the primary activities sector in urban settlements of Serbia is on average 2,29\% (in Bečej 25\%). In the period from 1981 to 2011. the share of active population working in the primary sector is on average reduced by about $3 \%$.

The study of changes in the structure of activities of population in the last 30 years and comparison with the results of research related to the period 1961-1981 the following regularities have been noted:

- In the majority of urban settlements (27), the share of employees in the secondary sector grew until 1981, and then began to decline; in major cities the peak was reached in 1961 (Belgrade and Novi Sad) and 1971 (Niš and Kragujevac).

- Permanent decrease of the share of employees in the secondary sector, from 1961 to 2011 was recorded in a small number of urban settlements (Paraćin, Leskovac and Bor).

- In all the analyzed urban settlements, the share of employees in tertiary-quaternary sector has reached a maximum in 2011, except 
in Valjevo and Zaječar, which have reached their maximum in 2002. Lazarevac is also an exception, as the only town in which the share of employees in the tertiary-quaternary sector has been steadily declining in the period 1961-2002, which is related to the mining complex in the immediate environment. The majority of the settlements (30) record constant increase of share of employees in the tertiaryquaternary sector, while in the centers of Belgrade, Kruševac and Vrbas one can not talk about the constant increase, but the maximum was certainly recorded in 2011. The centers of Kraljevo and Vranje the share of employees in tertiary-quaternary sector declined from 1961-1981, due to extreme industrialization, in order to subsequently grow until 2011 when it reached the maximum.

\section{Convergent evolution in the structure of activity}

Convergent evolution in the structure of activities in medium and large urban settlements (noted as the regularity of the research which we follow), which is characterized by a tendency for establishing and maintaining fairly uniform relations of employment in secondary sector, on one side, and tertiaryquaternary sector, on the other side (or by establishing equilibrium structure of activities), is evident in all tested urban areas. Early nineties are the time to establish the equilibrium structure of development activities - manufacturing and service sectors, on average in all urban settlements. However, there were significant differences in the centers individually, since in one centers the secondary sector was dominant, and in other centers - tertiary-quaternary sector was dominant (Тошић, Живановић, 2015). Divergence from established equilibrium structure of activitiesas a tendency, that had been observed in 1981 only in large cities, is a very clear characteristic today, both of mediumsized and smaller urban settlements, with ever more expressive dominance of tertiary-quaternary sector (of tested 39 urban settlements in 32 settlements divergence from equilibrium structure of activities was registered, according to the data in 2002, in order that this tendency was registered by 2011 in other urban settlements, with the exception of Lazarevac).

A number of settlements, such as Subotica, Pančevo, Novi Pazar, Leskovac, Zaječar, Sremska Mitrovica, Inđija, Bečej and Mladenovac achieved a functional equilibrium in the period from 1981 to 1991. when the process of industrialization of the country is slowing down and begins a qualitative development of the service sector, as a result of the achieved level of development. 
However, the process of qualitative strengthening and development of tertiary-quaternary sector was hinderedby the economic collapse that followed.

Table 5 - Period of achieving equilibrium structure of activities

\begin{tabular}{|c|c|l|}
\hline & $\begin{array}{c}\text { Number of } \\
\text { settlements }\end{array}$ & Names of settlements \\
\hline before 1961 & 5 & Belgrade, Novi Sad, Kraljevo, Požarevac and Vršac \\
\hline $1961-1971$ & 2 & Sombor, Ruma \\
\hline $1971-1981$ & 2 & Niš, Šabac \\
\hline $1981-1991$ & 9 & $\begin{array}{l}\text { Subotica, Pančevo, Novi Pazar, Leskovac, Zaječar, S. } \\
\text { Mitrovica, Inđija, Bečej, Mladenovac }\end{array}$ \\
\hline $1991-2002$ & 14 & $\begin{array}{l}\text { Kragujevac, Zrenjanin, Čačak, Smederevo, Valjevo, } \\
\text { Kruševac, Vranje, Užice, Jagodina, B.Palanka, } \\
\text { Prokuplje, Obrenovac, Paraćin, S.Palanka }\end{array}$ \\
\hline $2002-2011$ & 6 & $\begin{array}{l}\text { Pirot, Kikinda, Bor, Aranđelovac, G. Milanovac, } \\
\text { Vrbas }\end{array}$ \\
\hline after 2011 & 1 & Lazarevac \\
\hline
\end{tabular}

Note: Kruševac, Vranje, Šabac, Zaječar and Obrenovac had the dominance of tertiary-quaternary sector 1961, which they lost in later years, in order to again achieve dominance, not before 2002.

Source: authors

However, in most of the studied urban settlements (14) functional equilibrium is achieved only in the period 1991-2002 (Table 5, Map 1), which is actually a result of the collapse of the economy in Serbia in the nineties, which is primarily meant shutting down large industrial plants. This is exactly shown on the example of once strong industrial centers, such as Kragujevac, Obrenovac, Smederevo, as well as other urban settlements in which the share of employees in tertiary-quaternary sector surpassed the share of employees in the secondary sector, just when the industry in Serbia collapsed: Zrenjanin, Čačak, Valjevo, Kruševac, Vranje, Užice, Jagodina, Bačka Palanka, Prokuplje, Paraćin, Bela Palanka, etc.

Only in the settlements of Pirot, Kikinda, Bor, Aranđelovac, GornjiMilanovac and Vrbas, despite the closure of large industrial enterprises and the collapse of the manufacturing sector in the last decade of the last century, the secondary sector kept the dominance in order to, in the last census period, "give it up" to tertiary-quaternary sector. 


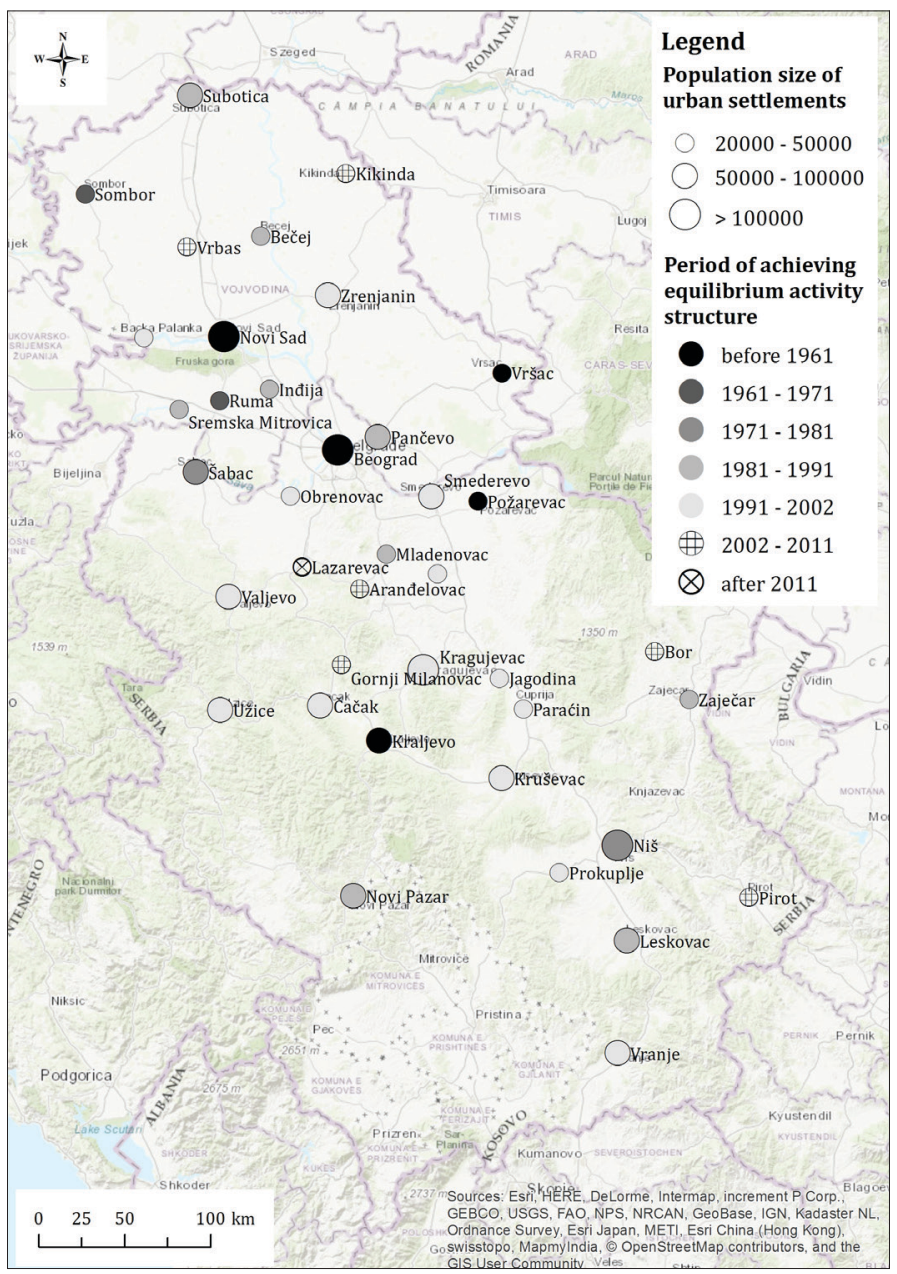

Map 1- Period of achieving equilibrium activity structure in the urban settlements

Table 6 - Average ratio of the share of employees in tertiary-quaternary and secondary sector activities in urban settlements with more than 20,000 inhabitants

\begin{tabular}{|c|c|c|c|c|c|c|c|c|c|}
\hline & \multicolumn{3}{|c|}{1991} & \multicolumn{3}{c|}{2002} & \multicolumn{3}{c|}{2011} \\
\cline { 2 - 9 } & $\mathbf{2 0 , 0 0 0 -}$ & $\mathbf{5 0 , 0 0 0 -}$ & $>$ & $\mathbf{2 0 , 0 0 0 -}$ & $\mathbf{5 0 , 0 0 0 -}$ & $>$ & $\mathbf{2 0 , 0 0 0}-$ & $\mathbf{5 0 , 0 0 0 -}$ & $>$ \\
$\mathbf{5 0 , 0 0 0}$ & $\mathbf{1 0 0 , 0 0 0}$ & $\mathbf{1 0 0 , 0 0 0}$ & $\mathbf{5 0 , 0 0 0}$ & $\mathbf{1 0 0 , 0 0 0}$ & $\mathbf{1 0 0 , 0 0 0}$ & $\mathbf{5 0 , 0 0 0}$ & $\mathbf{1 0 0 , 0 0 0}$ & $\mathbf{1 0 0 , 0 0 0}$ \\
\hline tq/s (average) & 1.00 & 1.00 & 2.13 & 1.25 & 1.48 & 2.34 & 1.86 & 2.19 & 3.25 \\
\hline
\end{tabular}

Source: SZS (1981); P3C (1991); P3C (2014a). 
The values of the tertiarization index (tq/s), as the ratio of the employment of tertiary-quaternary and secondary sector, clearly illustrate the intensity of the process of divergence from the equilibrium structure of activities. Namely, after the census of 1991 the average value of the tested indicators in urban settlements with less than 100,000 inhabitants shows that functional equilibrium was achieved, while in large cities the process of moving away from it has already begun. According to latest data, in urban areas with 50,000 to 100,000 inhabitants, the index surpassed the value of 2, which means that employment in the tertiary-quaternary sector twice as large in relation to employment in the secondary sector, while in big cities the average value of this indicator even 3.25 (Table 6).

\section{Dependence of population increase in the urban settlement of the level of development and the characteristics of its structure activity}

The existence of dependence of population increase in the urban settlement from the level of development and the characteristics of its structure of activities was noted in the study that covers the period 1961-1981 on more relations.

In urban settlements with less developed structure of activities, development is manifested in the form of strong and major changes in the structure of activities (strengthening the participation of some of the non-agrarian sector and significantly reducing the importance of the primary sector) and small, or even very small changes in the number of inhabitants. Such dependence in the period 1981-2011 was not identified, above all, since in the analysis not all urban settlements have been taken into account, i.e. those with more than 20,000 inhabitants, and the urban settlements with less than 20,000 inhabitants, according to Census data from 2011, the primary sector in the structure of activities has had minimal participation for a long time, which at the same time still decreases (in urban settlementson the territory of Vojvodinathe share of the active population performing occupation in the primary sector is considerably larger than in urban areas in Central Serbia, which confirms the conclusion that the urban settlements of Vojvodina are more rural than urban settlements in Central Serbia, and rural settlements are more urban, but only when it comes to functional amenities of rural settlements, but not when it comes to their structure of activities.

As far as changes in population, in the first reporting period 1981-1991 the maximum of the index of population growth was 118, the exceptions were only urban settlements: Lazarevac with 167, Gornji Milanovac with 126 
and Obrenovac, 123. In the next census period the maximum of the index of population growth was114 and in the last census period, only 110 (except in Novi Pazar 122, Novi Sad 121 and Lazarevac 114). However, number of settlements in which number of inhabitants decreases is growing. In the period from 1981 to 1991 population decline was recorded only in three settlements (all are on the territory of Vojvodina), in the next census period in 15 settlements, and in the period 2002-2011 even in the 24 urban settlements.

Another statement, defined as the result of research based on the data of which the latest was in 1981, and that "don't hold" any more, is that in urban settlements with developed structure of activities for a longer period more or less intense population growth was manifested. Namely, although structure of activities of analyzed urban settlements can be considered developed, with a tendency for further increase of share of employees in tertiaryquaternary sector and a reduction in the secondary and the primary sector, the population of these settlements since 1981 is not growing significantly, even considered to stagnate (average index growth 1981-1991 was 110, 19912002 was 102, and from 2002 to 2011 was 100), and in the last census period in a large number of settlements the number of inhabitants was reduced.

Hence, less developed structure of activities that includes significant presence of the primary sector, as the next phase of development in the creation of new nuclei in the field of industry or some of the tertiary-quaternary activities, which results in reducing the share of employees in the primary sector, with a minimal increase in population since the transfer of the labor force is carried from agricultural to non-agricultural activities within the urban settlements. When the share of employees in the primary sector has a low value as in urban settlements that have been analyzed here, further development of the economic structure should mean immigration of new workers from the immediate and wider environment and consequently increase of the number of inhabitants. However, in the urban settlements of Serbia with more than 20,000 inhabitants the number of inhabitants does not increase any more. Even, due to the exhaustion of the rural hinterland and a significant reduction of the intensity of immigration and, along with low or even negative value of the rate of natural population growth, the population in a larger number of urban settlements decreases. In this context, we emphasize the fact that even 35 tested settlements in the period 1991-2002 had negative natural population growth, and two settlements negative migration balance of definitive relocations on the municipal level. 
In terms of developed economic structure which is in Serbia accompanied by a reduction in the intensity of the immigration of inhabitants the conditions for the development of commuting system will be created. However, data on the share of commuters in the active population (from which is exempt active agricultural performing occupation and daily emigrants, and daily immigrants are included) indicate the existence of two regularities:

- in urban settlements in Serbia in which and tertiary-quaternary sector is significantly dominant - primarily Belgrade (Невенић, 2009), large and medium-sized urban settlements, or which are further away from the equilibrium structure of activity, the share of daily immigrants is decreased in relation to urban settlements that have low value of $\mathrm{tq} / \mathrm{s}$ index,

- in smaller urban settlementsthe share of daily commuters is twice higher (about 32\%) than in medium and large urban areas (about $16 \%)$, although the absolute number of daily commuters, with the increase in population of the central urban settlements, increases (information about daily migration refers to the year 2002).

\section{Conclusion}

Comparison of research results and to which are followed by the result of analysis conducted for the purpose of this paper suggest the following conclusions:

- regularities that were valid for large urban settlements in the period 1961-1981, at present, and according to the results of the last Census in 2011, are applicable to all urban settlements with more than 20,000 inhabitants,

- a slight increase or even decrease in population,

- the equilibrium structure of manufacturing and service industries was established (mainly in the period 1991-2002, 36\% of urban settlements)

- the small share of the primary sector of activity in active population, $2.3 \%$ (in the period 1961-1981 it was slightly less than 10\%),

- increasing dominance of tertiary-quaternary sector, which in 2011 has more than three times higher share then the secondary sector in large urban settlements, and nearly two times larger share in medium-sized urban settlements (in the period 1961-1981 the ratio of secondary and tertiary-quaternary sector ranged from 2:1 to 1:1). 
According to the criteria from the period 1961-1981 (Вељковић, et al. 1995), the present tendencies in the development of structures of activity show stagnation or regression, and this kind of population-functional development of the city, according to which cities have exhausted their development potential, since the changes in structure of activity are very weak, and the population has stagnated or even declined. Such estimates stem from the time when changes in the structure of activities sector were intensive and population growth in cities was significant.

Although tertiary-quaternary sector absolutely dominates in the structure of activity of analyzed urban settlements, it is clear that weakening of the secondary sector reduces the overall level of development and the actual importance of the size of the share of employees in tertiary-quaternary sector was brought into question, as an indicator of the development of the economic structure and overall development of observed urban settlements. Stability in sectors relations, regardless of only formal dominance of service activities, today does not mean a step backwards, especially when it comes to developed areas, but requires a more detailed analysis of changes between development activities within the tertiary-quaternary sector. This assesses the presence of certain activities that follow the modern trends, and the presence of technology and skills in accordance with the principles of flexible specialization and the innovation policy.

\section{Acknowledgements}

The paper is the result of the research within the projects no. 176017, 47006 and III 47014 funded by the Ministry of Education and Science of the Republic of Serbia.

\section{Reference}

Bole, D. (2011). Changes in Employee Commuting: A Comparative Analysis of Employee Commuting to Major Slovenian Employment Centers from 2000 to 2009. Acta geographica Slovenica, 51-1, pp 90-101.

Vogelnik, D. (1961). Urbanizacija kao odraz privrednog razvoja FNRJ, Ekonomska biblioteka, p.310, Beograd.

Vresk, M. (1996). Funkcionalna struktura i funkcionalna klasifikacija gradova Hrvatske. Geografski glasnik, 58. Zagreb.

Vresk, M. (2002). Grad i urbanizacija. Školska knjiga, Zagreb. 
Cercleux A-L, Peptenatu, D, Merciu, F-C (2015). Structural dynamics of tertiary activities in industrial parks in Bucharest, Romania. Acta geographica Slovenica, 55-2, pp. 272-281.

Erdem, U. (2016). Regional Human Capital Distribution and Disparities in Turkey. Review of Urban and Regional Development Studies. Vol. 28 Issue 1, pp. 16-31.

Fehre, H. (1971). Gemaeidetypennach Erwerbstruktur der Wohnbevolkerung. Raumforschung und Raumplannung, XIX, pp 137-148.

Kok, S., Weel ter, B, (2014). Cities, Tasks, and Skills. Journal of regional science, Vol. 54, No. 5, pp. 856-892.

Lobanov, M. (2014). Industrial activity in CEE countries: post-crisis transformation of spatial and functional structure. Collection of Papers - Faculty of Geography at the University of Belgrade, 62, 15-38.

Melo I., Ferreira-Lopes A., Monteiro H. (2015). Regional and sectoral foreign direct investment in Portugal since joining the European union: A dynamic portrait. Review of Urban and Regional Development Studies. Vol. 27, No. 3, pp. 197-229.

Mićić, V. (2015). Ponovna industrijalizacija i strukturne promene u funkciji ekonomskog razvoja Republike Srbije. Ekonomski horizonti, Vol. 17, Sv. 1, 15 - 31.

Moser, C. A, Scott, W. (1962). British Towns: A Statistical Study of their Social and Economic Differences. Population Vol. 17, No.3, 582-583.

Muneepeeraku, R., Jose Lobo, J., Shutters, T. Shade., Lievano, G. A., Qubbaj, R. M. (2013). Urban Economies and Occupation Space: Can They Get "There" from "Here"? PLOS ONE, Vol. 8 Issue 9, pp. 1-8.

Peračković, K. (2011). Hrvatska u postindustrijsko doba - promene u strukturi radno aktivnoga stanovništva po sektorima djelatnosti i spolu. Društvena istraživanja, br. 1(111), str. 89-110.

Santos, V. F., Vieira, W. C. (2015). Income Inequality in the Urban and Rural Sectors of the Northeast Region of Brazil. Review of Urban and Regional Development Studies. Vol. 27, Issue 2, pp 134-147.

Schmook, G. (1968). Wiskundig afgebakene ommelanden en hinterlanden van de Belgische steden op de basis van geselektioneerde diensten uit de tertiare sektor. Periodical K.N.A.G. (Koninklijk Nederlands Aardrijkskundig Genootschap), Geografisch Tijdschrift, Nieuwe Reeks, Deel II, Nr.4. 
Shearmur, R., Doloreux, D. (2008). Urban Hierarchy or Local Buzz? High-Order Producer Service and (or) Knowledge-Intensive Business Service Location in Canada, 1991-2001. The Professional Geographer, 60(3), pp. 333-355.

Sridhar, K. S. (2017). Economic Change and Specialization in India's Cities. Review of Urban and Regional Development Studies. Vol. 29 Issue 1, pp 63-87.

SZS (1981). Popis stanovništva 1981. Dokumentacioni materijal, Tabela 078, Beograd: Savezni zavod za statistiku (SZS).

Tacoli, C. (1997). The Changing scale and nature of rural-urban interactions: recent developments and new agendas, United Nations Centre for $\mathrm{Hu}-$ man Settlements (Habitat), Nairobi, 150-157.

Yoshito, H. (2016). Mathematically modelling proportions of Japanese populations by industry. Physica A, Vol. 460, pp 38-43.

Вељковић, А., Јовановић, Б., Р., Тошић, Б. (1995). Градови Србије-центри развоја у мрежи населја, Посебна издања Географског института “Јован Цвијић", САНУ, књ.44, Београд.

Живановић, 3. (2015). Градови средње величине - развојни центри на подручју Централне Србије. Посебно издање, Универзитет у Београду - Географски факултет, Београд.

Невенић, М. (2009). Значај Београда у социо-економском развоју Србије. Зборник радова Географркког факултета Универзитета у Београду, 57, 123-138.

РЗС (1991). Попис становништва 1991. Документациони материјал, Табела 007, Републички завод за статистику, Београд;

РЗС (2002). Дневни мигранти по насељима, Посебна обрада података, Београд: Републички завод за статистику (РЗС).

P3С (2004а). Попис становништва, домаћинстава и станова у 2002. Къ. 6, Делатност и пол активног становништва које обавља занимане. Београд: Републички завод за статистику (РЗС).

РЗС (2004б). Попис становништва, домаћинстава и станова 2002. у Републици Србији. Књ. 9, Упоредни преглед броја становника 1948, 1953, 1961, 1971, 1981, 1991. и 2002. Београд: Републички завод за статистику (РЗС).

Р3С (2014а). Попис становништва, домаћинстава и станова 2011. у Републици Србији. Къ. 15, Делатност - подаци по општинама и градовима. Београд: Републички завод за статистику (РЗС). 
РЗС (2014б). Попис становништва, домаћинстава и станова 2011. у Републиизи Србији. Къ. 20, Упоредни преглед броја становника 1948-2011. Београд: Републички завод за статистику (РЗС).

Тошић, Б. (1997). Градски регион - појам, карактеристике, одређивање и хијерархија. Географска структура и регионализаиија Србије I. Посебна издања Географског института „ЈованЦвијић“ САНУ, књ. 51, Београд.

Тошић, Д. (2012). Принципи регионализације. Географски факултет, Универзитет у Београду.

Тошић Б., Живановић, 3. (2015). Градски центри Србије у функцији развоја окружења. У 4. српски конгрес географра са међународним учешћем: Достигнућа, актуелности и изазови географске науке и праксе; поводом 150 година од роћења Јована Цвијића. Зборник радова књ. 1. Географски факултет, Универзитет у Београду и Српског графско друштво, Београд, 435-440. 